\title{
ANALISIS INVESTASI PEMBANGUNAN GUDANG PADA INDUSTRI PENGECORAN LOGAM
}

\author{
Aji Tulus Jatmiko, Irwan Soejanto dan Intan Berlianty \\ Prodi Teknik Industri \\ Jurusan Teknik Industri, Fakultas Teknik Industri \\ Universitas Pembangunan Nasional "Veteran" Yogyakarta \\ Jl. Babarsari 2 Tambakbayan, Yogyakarta, 55281 \\ Telp. (0274) 485363 Fak : (0274) 486256 \\ email : irwansoejanto@upnyk.ac.id
}

\begin{abstract}
ABSTRAK
Di tengah persaingan yang ketat, setiap perusahaan industri memiliki strategi dalam meningkatkan laba dan daya saing agar dapat bertahan. Salah satu strategi yang mendukungadalah sarana dan prasarana industri seperti sarana bangunan gedung. CV. AA. Teknik" merupakan salah satu industri manufaktur yang bergerak dibidang pengecoran logam.Industri mengalami kesulitan terkait dengan sarana gudang penyimpanan. Perusahaan menyewa gudang pada Koprasi Unit Desa (KUD) daerah setempat. Letak sewa gudang yang terlalu jauh dan kapasitas sewa gudang terlalu kecil mengakibatkan produktivitas pada perusahaan tersebut terhambat. Maka, pemilik industri berencana melakukan pembangunan gudang.

Untuk mengkaji permasalahan diatas, maka dilakukan analisis investasi yang meliputi aspek pasar, aspek teknis, dan aspek financial selama 10 periode. Modal awal investasi sebesar Rp. 124.861.000,00. Dalam aspek finansial kriteria penilaian investasi menggunakan metode Net Present Value(NPV) dengan tingkat pengembalian 15\%, Internal Rate of Return(IRR), Profitabitality Index(PI), dan Payback Period(PP).

Hasil dari penelitian berupa kesimpulan bahwa investasi pembangunan gedung layak dipertimbangkan berdasarkan aspek pasar, aspek teknis dan aspek finansial. Pada Aspek Finansial Net Present Value(NPV) sebesar Rp. 451.490.773,00. Internal Rate of Return(IRR) sebesar 32\% (IRR>15\%), Profitabitality Index(PI) sebesar 4,62(PI>1) dan pada Payback Periode (PP)investasi akan kembali selama 2 Tahun, 2 bulan, 23 Hari.
\end{abstract}

Kata Kunci : Kelayakan Investasi, Aspek pasar, Aspek Teknis, Aspek Finansial

\section{PENDAHULUAN}

Saat ini era perkembangan teknologi industri dan persaingan pasar bebas semakin ketat dan mengalami perkembangan yang pesat. Para pelaku industri dituntut untuk mempunyai strategi baru yang lebih baik guna memberikan hasil yang lebih optimal bagi perusahaan. Di tengah persaingan yang ketat tersebut, setiap perusahaan harus memiliki strategi yang tepat dalam meningkatkan laba industri dan daya saing agar perusahaan mampu tetap bertahan. Hal ini dapat dicapai salah satunya dengan keberadaan sarana dan prasarana industri yang mendukung.

CV. AA. Teknik merupakan salah satu industri manufaktur yang bergerak dibidang pengecoran logam. Produk yang dihasilkan industri ini adalah alat-alat perkakas pertanian, produk tersebut dipasarkan di daerah Jawa Tengah dan sekitarnya. Bahan baku yang digunakan adalah logam besi, bahan tersebut didapat dari daerah sekitar.
Berdasarkan observasi permasalah-an yang ada, CV. AA Teknik mengalami kesulitan dalam penyimpanan hasil produk jadi, dikarenakan tidak adanya sarana gudang pribadi. Selama ini perusahaan menyewa gudang pada Koperasi Unit Desa (KUD) daerah setempat, letak gudang sewa yang berada diluar lingkungan pabrik dan kapasitas yang terlalu kecil mengakibatkan proses pemyimpanan produk jadi mengalami keterhambatan. Apabila hal ini terus terjadi maka akan berkemungkinan terjadi penumpukan produk jadi pada lantai produksi, hal tersebut berpotensi menghambat proses produksi yang pastinya akan mengakibatkan kerugian pada industri CV. AA. Teknik. pemilik industri berencana melakukan pembangunan gudang penyimpanan sendiri dengan kapasitas yang lebih besar dan lokasi yang lebih strategis serta mempertimbangkan faktor bangunan gedung jangka panjang. Melihat kondisi ini maka perlu adanya suatu analisis kelayakan investasi pembangunan 
gudang Industri Pengecoran Logam "CV. AA Teknik" analisis ini berdasar pada aspek pasar, aspek teknis dan aspek finansial selama periode 10 tahun ke depan, dimana hal tersebut dilakukan untuk mengetahui pengaruh yang ditimbulkan terhadap kelayakan usaha.

\section{LANDASAN TEORI}

Investasi atau penanaman modal di dalam perusahaan tidak lain adalah menyangkut penggunaan sumber-sumber yang diharapkan akan memberikan imbalan/pengembalian yang menguntung-kan di masa yang akan datang (Suratman, 2001).

Studi kelayakan adalah pengkajian yang bersifat menyeluruh dan mencoba menyoroti segala aspek kelayakan proyek atau investasi (Soeharto, 1999). Tujuan dilakukannya studi kelayakan adalah untuk menghindari keterlanjutan penambahan modal yang terlalu besar untuk kegiatan yang ternyata tidak menguntungkan.

Peramalan adalah suatu proses untuk memperkirakan apa yang akan terjadi di masa yang akan datang. Berdasarkan tekniknya, metode peramalan dapat dikategorikan ke dalam metode kualitatif dan metode kuantitatif. (Baroto, 2002)

1. Peramalan Kualitatif, digunakan bila tidak ada atau sedikit data masa lalu yang tersedia. Dalam metode ini, pendapat pakar dan prediksi mereka dijadikan dasar untuk menetapkan permintaan yang akan datang.

2. Peramalan Kuantitatif, metode peramalan yang dikembangkan dari data kuantitatif masa lalu digunakan untuk mengektrapolasi (meramalkan) permintaan masa depan. Peramalan ini dapat dibedakan atas:

a. Metode Time Series (deret waktu) Langkah penting dalam memilih metode Time Series (deret waktu) adalah mempertimbangkan jenis pola data. Pola data dapat dibedakan menjadi empat jenis, yaitu:

1) Pola trend, data permintaan menunjukkan kecenderungan gerakan penurunan atau kenaikan jangka panjang. Metode yang digunakan adalah regresi linear, exponential smoothing atau double exponential smoothing. Pola data dapat dilihat pada Gambar 2.1.

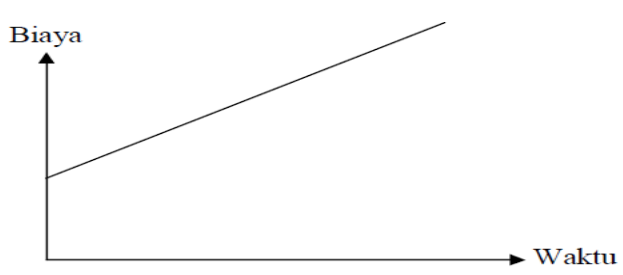

Gambar 2.1 Pola Trend

(Sumber: Jay Heizer,2005)

2) Pola musiman, terjadi bila data berfluktuasi terlihat berulang dalam suatu interval waktu tertentu, data tersebut berpola musiman. Metode yang digunakan adalah metode winter, moving average atau weight moving average. Pola data dapat dilihat pada Gambar 2.2.

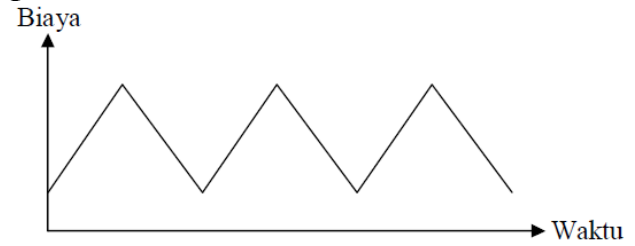

Gambar 2.2 Pola Musiman (Sumber: Jay Heizer,2005)

3) Pola siklikal, terjadi bila permintaan secara fluktuasi jangka panjang membentuk pola sinusoid atau gelombang atau siklus. Metode yang digunakan adalah metode moving average, weight moving average dan exponential smoothing. Bentuk dari pola data siklikal dapat dilihat pada Gambar 2.3.

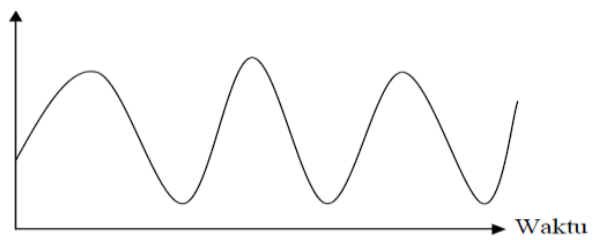

Gambar 2.3 Pola Siklikal

(Sumber: Jay Heizer,2005)

4) Pola eratik atau random, terjadi bila fluktuasi data permintaan dalam jangka panjang tidak dapat dihambarkan oleh ketiga pola lainnya. Tidak ada metode peramalan yang direkomendasikan untuk pola ini. Bentuk pola data random dapat dilihat pada Gambar 2.4.

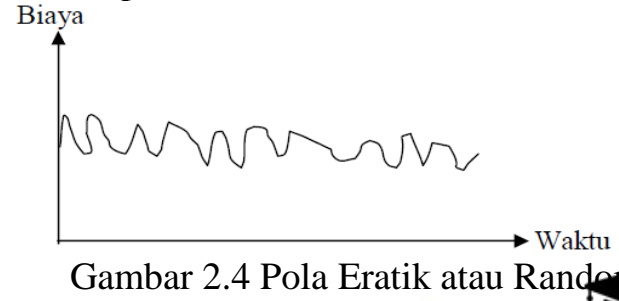


(Sumber: Jay Heizer,2005)

b. Metode Korelasi (sebab akibat) Metode peramalan yang didasarkan atas penggunaan analisis pola hubungan antara variabel yang akan diperkirakan dengan variabel lain yang mempengaruhinya (bukan waktu).

Adapun jenis - jenis teknik peramalan kuantitatif antara lain:

1) Moving average with linear trend, metode ini menggunakan rata - rata bergerak dengan factor trend dari data untuk mengurangi acakan dalam deret waktu tertentu. Tujuan ini dicapai dengan merata-ratakan beberapa nilai data secara bersamaan sehingga kesalahan positif atau negatif dapat dihilangkan.

2) Single exponential smoothing with linear trend, metode ini dihitung berdasarkan hasil peramalan ditambah dengan peramalan periode sebelumnya serta trend yang terjadi dari data sebelumnya.

3) Double exponential smoothing with linear trend, metode ini prinsipnya sama dengan Single exponential smoothing with linear trend. Perbedaannya adalah mengurangi atau memperbaiki kesalahan, metode ini dilakukan dua kali dengan menambah trend dari data sebelumnya.

Dari beberapa metode yang digunakan tersebut diambil metode yang mempunyai standar error terkecil.

Langkah - langkah dalam melakukan peramalan (Baroto, 2002):

1. Pendefisian tujuan peramalan yang dikehendaki.

2. Pembuatan diagram pancar dari data yang diperoleh.

3. Pemilihan paling sedikit dua metode sesuai dengan pola data untuk tujuan yang telah ditetapkan.

4. Menghitung kesalahan (standard error) untuk mengetahui performansi masing - masing metode yang digunakan.

5. Memilih metode terbaik dengan nilai kesalahan (standard error) terkecil.

6. Melakukan prediksi terhadap permintaan yang akan datang.

\section{Aspek - Aspek Studi Kelayakan}

Dalam melakukan studi kelayakan, terlebih dahulu mempelajari aspek-aspek apa saja yang berpengaruh. Pada umumnya akan dilakukan analisis terhadap aspek-aspek pasar, teknis, keuangan, hokum dan ekonomi. Pada penelitian ini hanya dilakukan pada aspek pasar, aspek teknis dan aspek finansial.

1. Aspek Pasar, Analisis aspek pasar mencakup hal-hal sebagai berikut:

a. Analisis banyaknya produksi masa lalu dan sekarang

b. Analisis banyaknya kebutuhan masa lalu dan sekarang termasuk penentuan jumlah dan nilai konsumsi

c. Estimasi pangsa pasar produk dengan mempertimbangkan banyaknya kebutuhan dan produksi

2. Aspek Teknis, menyangkut luas industri, model bangunan, proses produksi yang dilakukan, tata letak proses atau peralatan dan kapasitas produksi. Adapun aspek teknik meliputi:

a. Bangunan industri

b. Tata letak dan peralatan industri

c. Proses produksi

d. Kapasitas Produksi

3. Aspek Finansial, Menurut (Husnan dan Suwarsono, 2000), hal-hal yang perlu dipelajari berkaitan dengan aspek finansial adalah:

a. Dana yang disalurkan untuk investasi baik untuk aktiva tetap maupun untuk modal kerja.

b. Sumber-sumber pembelanjaan yang digunakan.

c. Taksiran penghasilan.

d. Proyeksi keuangan

e. Pembuatan neraca yang diproyeksikan dan proyeksi penggunaan dana.

f. Manfaat dan biaya seperti Net Present Value, Internal Rate of Return, Profitability Index dan Payback Period.

a. Menentukan Kebutuhan Dana Investasi, Pengalokasiannya dan Sumbernya.

b. Aliran Kas Proyek, usulan investasi harus didasarkan pada aliran kas (cash flow), karena untuk menghasilkan keuntungan tambahan harus mempunyai kas untuk ditanam kembali.

Pengertian aliran kas terdiri dari 2 macam yaitu:

1) Aliran Kas Keluar (cash out flow), adalah keseluruhan kas atau aktiva lain yang dapat dinilai dengan uang yang dikeluarkan sampai proyek tersebut menguntungkan. 
2) Aliran Kas Masuk (cash in flow), yaitu laba setelah ditambah pajak dengan depresiasi atau penyusutan.

Komponen Aliran Kas, Untuk mempermudah analisis, aliran kas proyek dikelompokkan menjadi tiga, yaitu:

1) Aliran Kas Awal (Initial Cash Flow)

2) Aliran Periode Operasi-Produksi (Operational Cash Flow)

3) Aliran Kas Akhir (Terminal Cash Flow)

Depresiasi dan Pajak, adalah penurunan dari alat atau properti atau aset karena waktu dan pemakaian (Pujawan, 2000).

Metode-metode dalam melakukan perhitungan penyusutan:

1) Metode Garis Lurus atau Straight Line Method (SL), Besarnya deprsiasi tiap tahun dengan metode SL dihitung berdasarkan:

$D t=\frac{P-S}{N}$

Keterangan

$D_{t}$ : besarnya depresiasi pada tahun ke-t

$\mathrm{P}$ : ongkos awal dari aset yang bersangkutan

$\mathrm{S}$ : nilai sisa dari asset tersebut

$\mathrm{N}$ : masa pakai (umur) dari asset tersebut dalam tahun

2) Metode Keseimbangan Menurun atau Declining Balance Method (DB), Metode ini bisa dipakai bila umur aset lebih dari 3 tahun. Persamaannya adalah:

$\mathrm{D}_{\mathrm{t}}=\mathrm{d}(1-\mathrm{d})^{\mathrm{t}-1} \mathrm{P}$

Keterangan

$D_{t}$ : besarnya depresiasi pada tahun ke-t

$\mathrm{D}$ :tingkat penyusutan yang ditetapkan

$\mathrm{P}$ :ongkos awal dari aset yang bersangkutan

Pajak adalah aliran kas, oleh karena itu pajak harus dipertimbangkan seperti halnya ongkosongkos yang lain (Pujawan, 2000). Fungsi pajak adalah (Waluyo,2000):

1) Fungsi Penerimaan (Budgetair).

2) Fungsi Mengatur (Reguler)

Analisis Penilaian, untuk mengukur atau menilai kelayakan suatu proyek terdapat beberapa kriteria yang digunakan:

1) Net Present Value (NPV), Untuk mengghitung $N P V$ yaitu:

$$
N P V=\sum_{t=0}^{n} \frac{B_{t}}{(1+i)^{t}}-\sum_{t=0}^{n} \frac{C_{t}}{(1+i)^{t}}=\sum_{t=0}^{n} \frac{B_{t}-C_{t}}{(1-i)^{t}}
$$

Keterangan

$N P V$ : Net Present Value (nilai sekarang)

$\mathrm{B}_{\mathrm{t}} \quad$ : aliran kas masuk tahun ke-t
$\mathrm{C}_{\mathrm{t}} \quad$ : aliran kas keluar tahun ke-t

$\mathrm{N}$ : umur unit usaha hasil investasi

I : tingkat bunga pengembalian

$\mathrm{T}$ : tahun ke

Kriteria penilaian:

Jika NPV > 0 , usulan proyek layak dipertimbangkan

Jika NPV < 0, usulan proyek ditolak

Jika NPV $=0$, maka nilai perusahaan tetap, walau usulan proyek diterima / ditolak

2) Internal Rate of Return (IRR), persamaan yang dipakai sebagai berikut:

$$
\mathrm{I} 0=\sum_{t=1}^{n} \frac{C F_{t}}{(1+I R R)^{t}}
$$

Keterangan Persamaan

$\mathrm{T}$ : tahun ke

n : jumlah tahun

$\mathrm{I}_{0} \quad$ : nilai investasi awal

$\mathrm{CF}_{\mathrm{t}}$ : arus kas bersih

IRR : tingkat bunga yang dicari harganya

Persamaan IRR untuk interpolasi:

$$
I R R=i_{1}+\left(\frac{N P V_{1}}{N P V_{1}-N P V_{2}}\right)\left(i_{2}-i_{1}\right)
$$

Keterangan

$\mathrm{i}_{1}$ : tingkat bunga ke-1 yang menghasilkan NPV $(+)$

$\mathrm{Pi}_{2}$ : tingkat bunga ke-2 yang menghasilkan NPV (-)

NPV (+): merupakan hasil percobaan pertama untuk nilai positif tingkat pengembalian $(+)$ yang baru digunakan

NPV (-): merupakan hasil percobaan kedua untuk nilai negatif tingkat pengmbalian yang baru digunakan

Kriteria penilaian:

$I R R>$ tingkat pengembalian (i) yang diinginkan, usulan proyek layak dipertimbangkan

$I R R$ < tingkat pengembalian (i) yang diinginkan, usulan proyek ditolak

$I R R=$ tingkat pengembalian (i) yang diinginkan, usulan proyek layak dipertimbangkan

3) Profitability Index (PI), dapat dihitung dengan membandingkan present value kas masuk dengan present value kas keluar.

$$
P I=\frac{\text { PresentValueKasMasuk }}{\text { PresentValueKasKeluar }}
$$

Kriteria penilaian: 
Jika PI > 1, usulan proyek dikatakan layak dipertimbangkan

Jika PI $<1$, usulan proyek dikatakan tidak layak

Jika PI $=1$, nilai perusahaan tetap, walau usulan proyek diterima atau ditolak

4) Payback Period, dibagi menjadi 2 yaitu:

a. Periode pengembalian, jika aliran kas tahunan jumlahnya tidak tetap. Persamaan yang digunakan (Soeharto, 1999):

$P P=(n-1)+\left[C f-\sum_{1}^{n-1} A n\right]\left(\frac{1}{A n}\right)$

Keterangan

Cf : biaya pertama

An: aliran kas pada tahun $n$

$\mathrm{N}$ : tahun pengembalian ditambah 1

b. Periode pengembalian, jika arus kas tahunan jumlahnya tetap. Persamaan yang digunakan (Soeharto, 1999):

$P P=\frac{C f}{A}$

Keterangan Persamaan

Cf : biaya pertama

A : arus kas bersih per tahun

\section{METODOLOGI PENELITIAN}

Data yang diperlukan dalam penelitian ini adalah:

1. Data aspek pasar, yaitu data permintaan dan penjualan produk di wilayah Sragen dan sekitarnya.

2. Data aspek teknis, yaitu luas lahan yang akan dibangun, model bangunan, proses produksi dan tata letak (layout) industri, kapasitas produksi, target produksi.

3. Data aspek finansial, seperti, besarnya modal investasi Industri Pengecoran Logam "CV. AA Teknik", perkiraan jumlah pengeluaran serta pendapatan yang diterima. Adapun teknik-teknik yang digunakan dalam penelitian tersebut adalah:
a. Observasi.
b. Wawancara
c. Studi Pustaka
d. Dokumentasi

\section{HASIL DAN PEMBAHASAN}

\subsection{Analisis Hasil}

Berdasarkan hasil pengolahan yang telah dilakukan, penilaian investasi "CV.AA Teknik" dapat dijelaskan dalam beberapa aspek. Pertama, Aspek pasar berdasarkan peramalan permintaan dan penjualan didapatkan perkiraan peluang pasar yang terus meningkat disetiap tahunnya. Kedua, Aspek teknis meliputi pembangunan gudang seluas $100 \mathrm{~m}^{2}$ dengan

total biaya pembangunan gudang sebesar Rp. 116.861.000,00, kegiatan pembangunan gudang Industri Pengecoran Logam "CV.AA Teknik"dilakukan selama 4 bulan. Ketiga, Aspek finansial berdasarkan hasil perhitungan 124.861.000,00 sehingga didapat hasil dari analisis perhitungan investasi NPV sebesar Rp. 451.490.773,00 (NPV>0), hal tersebut menunjukkan keuntungan bersih Industri Pengecoran Logam "CV. AA Teknik" yang besar. IRR yang didapat sebesar $32 \%$, IRR tersebut menunjukkan lebih besar dari tingkat pengembalian yang ditetapkan oleh pemilik industri yaitu $15 \%$. Profitability Index sebesar 4,62 (PI>1), dan Payback Period adalah selama 2 Tahun, 2 Bulan, 23 Hari. Hal tersebut menunjukan bahwa jangka waktu yang diperlukan untuk mengembalikan modal investasi lebih kecil dari jangka waktu analisis yaitu 10 tahun. Berdasarkan perhitungan yang dilakukan maka didapat laba bersih di tahun ke 10 ( batas waktu analisis kelayakan investasi), dimana laba bersih perusahaan dengan adanya pembangunan gudang baru adalah sebesar Rp.1.202.361.204,00 (dapat dilihat pada Lampiran E) berbanding dengan laba bersih perusahaan dengan tetap mempertahankan sewa gudang adalah sebesar Rp. 1.035.864.255,00, dengan selisih sebesar Rp. 166.496.949,00 dalam kurun waktu analisis 10 tahun atau Rp. 13.874.745,00 /tahun. Hal tersebut menunjukan keuntungan perusahaan yang lebih besar justru dengan melakukan pembangunan gudang baru.

\subsection{Analisis Sensitivitas}

Digunakan untuk menghadapi kondisi akibat perubahan-perubahan dari pencapaian target dan rencana anggaran pendapatan proyek Industri Pengecoran Logam "CV. AA Teknik" analisis sensitivitas ditujukan pada dua faktor yang dianggap berpengaruh yaitu pendapatan dan pengeluaran.

\section{KESIMPULAN 5.1 Kesimpulan}


Berdasarkan pada pengolahan data dan pembahasan yang telah dilakukan sebelumnya dapat disimpulkan bahwa

1. Pada aspek pasar, masih terdapat peluang pada Industri Pengecoran Logam "CV. AA Teknik" yang terus menerus meningkat setiap tahunnya sehingga proyek layak untuk dipertimbangkan dan tidak berpengaruh terhadap kelayakan usaha.

2. Pada aspek teknis, konstruksi bangunan gudang disesuaikan dengan kebutuhan dan dengan tata letak yang sesuai.

3. Pada aspek finansial proyek ini layak dipertimbangkan. Hal ini dapat dilihat dari:

a. Nilai NPV dengan tingkat pengembalian $15 \%$ positif $(\mathrm{NPV}>0)$, yaitu $\mathrm{Rp}$ 451.490.773,00.

b. Internal Rate of Return sebesar 32\% (IRR $>15 \%)$

c. Profitability Index sebesar 4,62 (PI>1)

d. Payback Period yang lebih kecil dari jangka waktu analisis yang ditetapkan (10 tahun), yaitu sebesar 2 Tahun, 2 Bulan, 23 Hari.

e. Laba bersih di tahun ke 10 ( batas waktu analisis kelayakan investasi) perusahaan dengan adanya pembangunan gudang baru adalah sebesar Rp.1.202.361.204,00 dan laba bersih perusahaan dengan tetap mempertahankan sewa gudang adalah sebesar Rp. 1.035.864.255,00. Hal tersebut menunjukan keuntungan perusahaan yang lebih besar justru dengan melakukan pembangunan gudang baru.

f. Dari analisis sensitivitas baik perubahan pendapatan $(-10 \%$ dan $-15 \%)$ maupun perubahan pengeluaran $(10 \%$ dan $15 \%$ ) proyek ini tidak sensitif terhadap perubahan yang terjadi dengan demikian proyek ini dikatakan layak untuk dipertimbangkan

\subsection{Saran}

Berdasarkan hasil kesimpulan di atas, maka peneliti dapat memberikan saran bahwa pemilik industri sebaiknya segera menyelesaikan pembangunan gudang produk industri agar proses pembangunannya dapat berjalan dan selesai tepat waktu. Sehingga proses produksi dapat berjalan dengan maksimal dan memberikan kenyamanan serta keamanan bagi semua komponen Industri Pengecoran Logam "CV. AA Teknik”.

\section{DAFTAR PUSTAKA}

Gaspersz, V., 2004, Production Planning and Inventory Control, PT Gramedia Pustaka, Jakarta.

Adiguna, R., 2008, Skripsi, Analisis Kelayakan Investasi Pembangunan Pabrik Minyak Kelapa Sawit (PMKS),Universitas Sumatera Utara.

Baroto, T., 2000, Perencanaan dan Pengendalian Produksi, Ghalia Indonesia, Jakarta.

Fahmi, L.P., 2013,Skripsi, Usulan Perbaikan Tata LetakFasilitas Produksi pada Industri Mebel dengan Algoritma Craft, Fakultas Teknologi Industri, Progam Studi Teknik Industri, Universitas Pembangunan Nasional Veteran Yogyakarta

Ihwan, K., 2010, Skripsi, Studi Kelayakan Investasi Pabrik Asap Cair di Pulau Kijang, Fakultas Sains Dan Teknologi, Program Studi Teknik Industri, Universitas Islam Negeri Sunan Kalijaga Yogyakarta.

Jay Heizer, Barry Render., 2009, Manajemen Operasi, Salemba Empat, Jakarta.

Kristiani, Z., 2014, Analisis Ketersediaan dan Permintaan Beras dengan Pendekatan System Dynamic, Fakultas Teknologi Industri, Jurusan Teknik Industri, Universitas Pembangunan Nasional Yogyakarta.

Kurniawati, E.M., 2006, Model untuk Menyelesaikan Persoalan Tata Letak Fasilitas Multi-floor pada Industri Jasa, Fakultas Teknologi Industri, Jurusan Teknik Industri, Universitas Pembangunan Nasional Yogyakarta.

Moch., D., 2008, Analisis Kelayakan Investasi untuk Rencana Perluasan Jaringan pada PT. Telkom (Persero)Cabang Malang, Skripsi, Fakultas Ekonomi, Jurusan Manajemen, Universitas Islam Negeri Malang.

Permatasari, I.A., 2015, Skripsi, Perancangan Sistem Informasi Harga Pokok Produksi pada UD M.Joint, Fakultas Teknologi Industri, Progam Studi Teknik Industri, Universitas Pembangunan Nasional Veteran Yogyakarta.

Pujawan, I., 2003, Ekonomi Teknik, Edisi pertama, Guna Widya, Surabaya. 
Soeharto, I., 1999, Manajemen Proyek, Edisi kedua jilid 1, Erlangga, Jakarta.

Sujatmiko, S., 2012, Skripsi, Analisis Kelayakan Investasi Penambahan Alat Produk Usaha Chandra Convection, Fakultas Ekonomi, Program Studi Manajemen, Universitas Muria Kudus.

Sumyarningsih, A., 2007, Skripsi, Analisis Kelayakan Investasi Perbaikan Gedung pada Industri Pengecoran Aluminium, Fakultas Teknologi Industri, Progam Studi Teknik Industri, Universitas Pembangunan Nasional Veteran Yogyakarta.

Suratman, 2000, Studi Kelayakan Proyek, Edisi Pertama, J\&J Learning, Yogyakarta.
Waluyo, 2000, Perubahan Perundang Undangan Era Reformasi, Salemba Empat, Jakarta.

Waluyo, 2002, Perpajakan Indonesia, Salemba Empat, Jakarta.

Wandasari, D.W., 2011, Skripsi, Analisis Sistem Pengendalian dan Perencanaan Persediaan Obat-Obatan serta AlatKesehatan di Institusi Penyedia Layanan Jasa Kesehatan Swasta, Fakultas tekik, Progam Studi Teknik Industri, Jurusan Teknik Mensin dan Industri, Universitas Gadjah Mada Yogyakarta. 